\title{
IN VITRO CONSERVATION OF DIPLOID BANANA ACCESSIONS
}

\author{
Roberto Pedroso de Oliveira ${ }^{1 *}$; Sebastião de Oliveira e Silva²; Keuder Magalhães da Silva²; \\ Daniela Garcia Silveira ${ }^{3}$ \\ ${ }^{1}$ Embrapa Clima Temperado, C.P. 403 - CEP: $96001-970$ - Pelotas, RS. \\ ${ }_{3}^{2}$ Embrapa Mandioca e Fruticultura, C.P. 7 - CEP: 44380-000 - Cruz das Almas, BA. \\ ${ }^{3}$ Escola de Agronomia da Universidade Federal da Bahia, CEP: 44380-000 - Cruz das Almas, BA \\ *Corresponding author <rpedroso@cena.usp.br>
}

ABSTRACT: A protocol for the in vitro conservation of diploid banana accessions based on lower temperature for culture environment was developed. Twenty four genotypes, four clones per genotype were studied. After disinfection, shoot tips $(0.5 \mathrm{~cm}$ diameter $\times 0.5 \mathrm{~cm}$ height) were established in vitro and submitted to multiplication induced by benzylaminopurine. Twelve explants $(0.6 \mathrm{~cm}$ diameter $\times 1.2 \mathrm{~cm}$ height $)$ from each accession were transferred to the MS medium supplemented with $20 \mathrm{~g} \mathrm{~L}^{-1}$ sucrose and $2 \mathrm{~g} \mathrm{~L}^{-1}$ Phytagel, without growth regulators, under light intensity of 2000 lux, 16-hour photoperiod, at temperatures of: $17 \pm 2^{\circ} \mathrm{C}, 22 \pm 2^{\circ} \mathrm{C}$ and $26 \pm 2^{\circ} \mathrm{C}$. The development of plantlets was evaluated during 450 days and the survived plantlets were acclimated under greenhouse conditions. There were no differences among genotypes concerning the behavior during in vitro conservation; all genotypes showed potential to be conserved for a long time. The interval for transference should be 180, 360 and 450 days under the mean temperatures of 26,22 and $17^{\circ} \mathrm{C}$, respectively.

Key words: Musa spp., germplasm, in vitro conservation

\section{CONSERVAÇÃO IN VITRO DE ACESSOS DIPLÓIDES DE BANANEIRA}

\begin{abstract}
RESUMO: Foi desenvolvido um protocolo para conservação in vitro de acessos diplóides de bananeira, baseando-se na redução da temperatura da sala de cultivo. Foram utilizadas como matrizes, quatro mudas do tipo chifrinho de 24 genótipos. Após desinfestação, ápices caulinares $(0,5 \mathrm{~cm}$ diâmetro $\times 0,5 \mathrm{~cm}$ altura) foram introduzidos in vitro e submetidos à multiplicação induzida por benzilaminopurina. Após esta fase, 12 explantes (0,6 cm de diâmetro por $1,2 \mathrm{~cm}$ de altura) de cada acesso foram introduzidos em meio de conservação (MS contendo $20 \mathrm{~g} \mathrm{~L}^{-1}$ de sacarose e $2 \mathrm{~g} \mathrm{~L}^{-1}$ de Phytagel), sem fitorreguladores, a qual foi realizada sob intensidade luminosa de 2000 lux, fotoperíodo de 16 horas, sob temperaturas de: $17 \pm 2{ }^{\circ} \mathrm{C}, 22 \pm 2^{\circ} \mathrm{C}$ ou $26 \pm 2^{\circ} \mathrm{C}$. $\mathrm{O}$ desenvolvimento das plântulas foi analisado durante 450 dias e as plântulas sobreviventes foram aclimatadas em casa-de-vegetação. Não foram observadas diferenças entre os acessos quanto ao seu comportamento in vitro; todos apresentaram potencial para serem conservados por longos períodos. $O$ intervalo entre as transferências deve ser de 180, 360 e 450 dias, sendo que as temperaturas médias devem ser mantidas a 26, 22 e $17^{\circ} \mathrm{C}$, respectivamente.
\end{abstract}

Palavras-chave: Musa spp., germoplasma, conservação in vitro

\section{INTRODUCTION}

Banana crop involves billions of dollars per year all over the world and more than 35 millions of people depend on this agricultural activity (Arias, 1993).

One of the Brazilian Embrapa Research Centers (CNPMF) is dedicated to tropical fruit research. It is located in Cruz das Almas, BA and has a banana breeding program that consists in obtaining more productive and pest, and disease tolerant tetraploid cultivars which yield fruits with better quality, by selecting among bred diploid and commercial triploid progenies.

The active bank of banana germplasm at CNPMF has 280 classified accessions in which 232 are already characterized and evaluated, using 107 agricultural botanical descriptors. Among these accessions, $86 \%$ are cultivars and $14 \%$ are native species.

The preservation of banana germplasm can be done by means of collection in the field, seed bank (diploids) and in laboratories under reduced growth conditions or cryopreservation (Escalant, 1993). The in vitro banana collections under minimal growth conditions show, as advantage, the easiness for exchanging germplasm compared with the field collections. This advantage is due to the reduced weight and volume of in vitro plants, minimal possibility of disease dissemination and more pronounced control of environmental conditions. Moreover, the accessions can be rapidly multiplied and the whole process demands small space and labor (De Langue, 1984; Jarret, 1986; Vuylsteke, 1989). The seed conservation in banana is limited by the fact that various diploids do not yield fertile seeds (Williams, 1987). Although Withers (1990) and Panis (1995) described protocols for cryopreservation of banana suspension cells, a system to reduce risks of somaclonal variation was not yet developed.

The in vitro conservation by minimal growth rate of the plantlets can be done by addition of osmotic stabilizers such as sorbitol, manitol or sucrose in culture medium (Zamora et al., 1986), and/or by reducing temperature of the culture environment (Vuylsteke, 1989). 
Temperatures between 15 and $21^{\circ} \mathrm{C}$ in conservation chambers are frequently utilized to reduce the growth rate (Banerjee \& De Langhe, 1985; Jarret et al., 1986; Van Den Houwe et al., 1995).

However, it is necessary for each species, even for each accession to define factors such as composition of culture medium, conservation chamber temperature and period of transference to maximize the efficiency of conservation (Withers, 1990). The conserved material also needs to be monitored concerning its genetic stability, viability and phytosanitary state.

The aim of the present work was to develop a protocol for in vitro conservation of diploid banana (AA) accessions based on the reduction of the temperature of the conservation chamber.

\section{MATERIAL AND METHODS}

Twenty four accessions of diploid bananas were studied (TABLE 1) and, four clones per genotype were used. The suckers were washed with tap water and cut into explants of $1.2 \mathrm{~cm}$ diameter and $3.0 \mathrm{~cm}$ height. The explants were surface sterilized in $70 \%$ ethanol $(\mathrm{v} / \mathrm{v})$ for 3 minutes and in $6 \%$ calcium hypochloride solution for 20 minutes. They were rinsed three times in sterile distilled water, and reduced to $0.5 \mathrm{~cm}$ diameter and $0.5 \mathrm{~cm}$ height.

TABLE 1 - Type and origin of banana diploid accessions (AA).

\begin{tabular}{|c|c|c|}
\hline Accession & Type & Origin \\
\hline F3P 4 & Partenocarpic hybrid & Equator \\
\hline Jaran & Cultivar & Ind onesia \\
\hline Khae & Wild & Thailand \\
\hline Khai & Cultivar & Thailand \\
\hline Lidi & Cultivar & Honduras \\
\hline$M-53$ & Partenocarpic hybrid & Equator \\
\hline M-61 & Partenocarpic hybrid & Equator \\
\hline Malaccensis & Wild material & Honduras \\
\hline Malbut & Cultivar & New Guinea \\
\hline Mambe Thu & Cultivar & New Guinea \\
\hline Monyet & Wild material & Indonesia \\
\hline NBC-20 & Cultivar & New Guinea \\
\hline Niyarma Yik & Cultivar & New Guinea \\
\hline Ouro & Cultivar & Brazil \\
\hline Pa Phatthalung & Wild material & Thailand \\
\hline PA Rayong & Wild material & Thailand \\
\hline PA Songkla & Wild material & France \\
\hline Raja Uter & Cultivar & Ind one sia \\
\hline S/N. 2 & Cultivar & New Guinea \\
\hline Sowmuk & Cultivar & New Guinea \\
\hline Thong Dokmak & Cultivar & Thailand \\
\hline Tjau Lagada & Cultivar & Honduras \\
\hline Tongat 1 & Cultivar & Honduras \\
\hline Tuugia & Cultivar & Hawaii \\
\hline
\end{tabular}

Scientia Agricola, v.57, n.2, p.245-249, abr./jun. 2000
Explants were cultured on MS (Murashige \& Skoog, 1962) medium supplemented with $2 \mathrm{mg} \mathrm{L}^{-1} \mathrm{BA}$ (benzylaminopurine), $30 \mathrm{~g} \mathrm{~L}^{-1}$ sucrose and $2 \mathrm{~g} \mathrm{~L}^{-1}$ Phytagel, and the $\mathrm{pH}$ was adjusted to 5.7 before autoclavage (cultures were maintained for 4 weeks under 2000 lux, 16 h photoperiod and temperature of $27^{\circ} \mathrm{C} \pm 2^{\circ} \mathrm{C}$ ). Explants were then subcultured three times every four weeks in the MS medium supplemented with $3 \mathrm{mg} \mathrm{L}^{-1} \mathrm{BA}, 30 \mathrm{~g} \mathrm{~L}^{-1}$ sucrose and $2 \mathrm{~g} \mathrm{~L}^{-1}$ Phytagel, under the same physical conditions. Twelve rooted plantlets of each accession were individualized. The roots and pseudostems were pruned off, leaving the explants with $0.6 \mathrm{~cm}$ diameter and $1.2 \mathrm{~cm}$ height. Each explant was transferred to a test tube $(25 \mathrm{x}$ $150 \mathrm{~mm}$ ) containing $20 \mathrm{~mL}$ of the MS medium supplemented with $20 \mathrm{~g} \mathrm{~L}^{-1}$ sucrose and $2 \mathrm{~g} \mathrm{~L}^{-1}$ Phytagel, devoid of growth regulators. Conservation was done under 2000 lux light intensity, $16 \mathrm{~h}$ photoperiod and at three temperatures: $17 \pm 2,22 \pm 2$ and $26 \pm 2^{\circ} \mathrm{C}$. Four plantlets per treatment were used. The survival rate, plantlet height, tissue oxidation level and root formation were evaluated each 90 days. After 450 days, the surviving plantlets were acclimated under greenhouse conditions and transferred to the field.

\section{RESULTS AND DISCUSSION}

Explant contamination concerning the 24 accessions was on the average $13 \%$ at the establishment, $7 \%$ at the multiplication stage and less than $1 \%$ during the conservation period. Similar results were obtained at the multiplication of several banana cultivars (Sandoval et al., 1991; Leifert et al., 1994). The use of Phytagel instead of agar was favorable, since the development of bacteria and fungi was quickly identified in the cultures. The losses by microbial contamination were reduced during conservation.

Average number of multiplied explants varied from 2 to 3.4 plantlets per subculture, depending on the accession. The multiplication rates reported in this kind of work varies from 2 to 10 plantlets per subculture in several diploid, triploid and tetraploid banana accessions (Banerjee \& De Langhe, 1985; Vuylsteke \& De Langhe, 1985; Wong, 1986). Although significant differences occur as function of the genotype, the propagation method used in the present work was reasonable to multiply the accessions studied.

High survival rates of the explants were observed, even at a lower conservation temperature (TABLE 2). According to Banerjee \& De Langhe (1985), physiological damage happens at temperatures lower than $10^{\circ} \mathrm{C}$ and in vitro growth of banana plantlet stopped at temperature lower than $12^{\circ} \mathrm{C}$. Although none of plants of the accessions S/N.2, Thong Dokmak and Tuugia survived under mean temperatures of $17^{\circ} \mathrm{C}$, it can not be concluded that they are sensitive to low temperature because of the small number of replicates used.

As was expected, the in vitro plantlet growth was higher with the increase of the temperature of the 
TABLE 2 - Effect of temperature on banana diploid accessions (AA) survival along 450 days of culture.

\begin{tabular}{|c|c|c|c|c|c|c|c|c|c|c|c|c|c|c|c|}
\hline \multirow{3}{*}{$\begin{array}{l}\text { Accession } \\
\text { Number of days } \\
\text { Temperature }^{1}\end{array}$} & \multicolumn{15}{|c|}{$\%$ Survival } \\
\hline & \multicolumn{3}{|c|}{90} & \multicolumn{3}{|c|}{180} & \multicolumn{3}{|c|}{270} & \multicolumn{3}{|c|}{360} & \multicolumn{3}{|c|}{450} \\
\hline & 17 & 22 & 26 & 17 & 22 & 26 & 17 & 22 & 26 & 17 & 22 & 26 & 17 & 22 & 26 \\
\hline F3P4 & 100 & 0 & 100 & 100 & 0 & 100 & 100 & 0 & 75 & 100 & 0 & 0 & 100 & 0 & 0 \\
\hline Jaran & 100 & 100 & 100 & 100 & 100 & 100 & 75 & 50 & 50 & 75 & 50 & 50 & 75 & 25 & 0 \\
\hline Khae & 50 & 100 & 100 & 50 & 100 & 100 & 50 & 50 & 0 & 50 & 50 & 0 & 50 & 25 & 0 \\
\hline Khai & 50 & 50 & 50 & 50 & 50 & 50 & 50 & 50 & 50 & 50 & 50 & 50 & 50 & 50 & 0 \\
\hline Lidi & 100 & 100 & 50 & 100 & 100 & 50 & 100 & 50 & 0 & 100 & 50 & 0 & 100 & 50 & 0 \\
\hline$M-53$ & 100 & 100 & 50 & 75 & 100 & 50 & 50 & 75 & 25 & 50 & 75 & 25 & 50 & 25 & 0 \\
\hline$M-61$ & 100 & 100 & 100 & 100 & 100 & 100 & 100 & 100 & 100 & 100 & 100 & 100 & 75 & 75 & 25 \\
\hline Malaccensis & 100 & 100 & 50 & 100 & 100 & 0 & 100 & 100 & 0 & 100 & 100 & 0 & 75 & 100 & 0 \\
\hline Malbut & 100 & 100 & 100 & 50 & 100 & 100 & 50 & 100 & 50 & 50 & 100 & 50 & 50 & 75 & 0 \\
\hline Mambe Thu & 100 & 100 & 100 & 100 & 100 & 100 & 100 & 100 & 100 & 100 & 100 & 100 & 75 & 75 & 0 \\
\hline Monyet & 100 & 100 & 100 & 100 & 100 & 100 & 100 & 100 & 25 & 100 & 100 & 25 & 100 & 100 & 0 \\
\hline NBC-20 & 100 & 100 & 50 & 75 & 50 & 50 & 50 & 50 & 50 & 50 & 50 & 0 & 50 & 50 & 0 \\
\hline Niyarma Yik & 100 & 100 & 100 & 100 & 100 & 100 & 100 & 100 & 50 & 100 & 100 & 50 & 100 & 75 & 25 \\
\hline Ouro & 100 & 100 & 100 & 100 & 100 & 100 & 100 & 100 & 100 & 100 & 100 & 50 & 100 & 75 & 0 \\
\hline PA Rayong & 100 & 100 & 100 & 100 & 100 & 75 & 100 & 100 & 25 & 100 & 100 & 25 & 100 & 100 & 0 \\
\hline PA Songkla & 100 & 100 & 100 & 100 & 100 & 100 & 75 & 100 & 100 & 75 & 100 & 100 & 75 & 50 & 25 \\
\hline Phatthalung & 100 & 50 & 100 & 100 & 50 & 100 & 100 & 50 & 100 & 100 & 50 & 100 & 100 & 50 & 25 \\
\hline Raja Uter & 100 & 100 & 0 & 25 & 100 & 0 & 0 & 100 & 0 & 0 & 100 & 0 & 0 & 75 & 0 \\
\hline S/N.2 & 50 & 100 & 100 & 0 & 50 & 100 & 0 & 50 & 75 & 0 & 50 & 50 & 0 & 25 & 0 \\
\hline Sowmuk & 100 & 100 & 100 & 100 & 100 & 100 & 100 & 100 & 100 & 100 & 100 & 100 & 100 & 100 & 0 \\
\hline Thong Dokmak & 100 & 100 & 100 & 0 & 100 & 50 & 0 & 100 & 0 & 0 & 100 & 0 & 0 & 50 & 0 \\
\hline Tjau Lagada & 100 & 100 & 50 & 100 & 100 & 50 & 100 & 100 & 50 & 100 & 100 & 0 & 100 & 50 & 0 \\
\hline Tongat 1 & 75 & 75 & 75 & 50 & 50 & 50 & 50 & 50 & 0 & 50 & 50 & 0 & 50 & 25 & 0 \\
\hline Tuugia & 50 & 100 & 100 & 0 & 100 & 100 & 0 & 50 & 50 & 0 & 50 & 50 & 0 & 50 & 25 \\
\hline
\end{tabular}

Mean temperature during the period of conservation.

conservation chamber (TABLE 3). At the first 180 days, the plantlets which were maintained at $26^{\circ} \mathrm{C}$ showed leaf and root growth three to four times higher on the average than the observed under $17^{\circ} \mathrm{C}$. At the end of 180 days, all plantlets cultured at $26^{\circ} \mathrm{C}$ reached to the top test tub (12 $\mathrm{cm})$. This in vitro growth was only observed after 360 days at the treatments of $17^{\circ} \mathrm{C}$ and $22^{\circ} \mathrm{C}$ (TABLE 3).

During the period of conservation, no differences in development among the accessions were observed. However, Banerjee \& De Langhe (1985) verified that the cultivars of plantain Asamiensa Agbagba and Ntanga $(A A B)$ and Bluggoe (ABB) were more tolerant to low temperature than the cultivars of Dwarf Cavendish and Pisang Nangka (AAA). Zamora et al. (1989) verified that genotypes of the $A A$ and $A A A$ groups had higher survival rates than those of the $A B B$ and $B B B$ groups under the same conditions. These results indicate that further research is necessary.

At first 90 days, the plantlets had vigorous green leaves below $26^{\circ} \mathrm{C}$ and yellow-green leaves below $17^{\circ} \mathrm{C}$. Later on, the leaves of the conserved plantlets became more yellowish proportionally to the increase of temperature. After 180 days, the plantlets at $26^{\circ} \mathrm{C}$ started showing signals of senescence. At 270 days, the leaves showed necrotic spots and high browning grade. Cases of death were more common at this time. Therefore, for diploid (AA) bananas conserved at $26^{\circ} \mathrm{C}$, the subcultures should be done every 180 days. Zamora et al. (1986) verified that the in vitro conservation of banana species could be carried at multiplication temperatures, but the subcultures should be done every two months, requiring more labor, reagents and increasing risks of contamination losses. The time when the in vitro material should be replicated depends on different factors such as survival rate, viability and genetic stability.

Even after 360 days of conservation, the plantlets showed strong green color, low browning level, normal root development when grown at $17^{\circ} \mathrm{C}$ or below. Although they had reached the total height of the test tubes, the plants were perfectly healthy to be kept under the same conditions without replicating. The plantlets grown under mean temperature of $22^{\circ} \mathrm{C}$ at this day showed an intermediate behavior requiring replication. Van Den Houwe et al. (1995), working with 41 banana clones maintained at 
TABLE 3 - Effect of temperature on banana diploid plantlets (AA) height along 450 days of culture.

\begin{tabular}{|c|c|c|c|c|c|c|c|c|c|c|c|c|c|c|c|}
\hline \multirow{3}{*}{$\begin{array}{l}\text { Accession } \\
\text { Number of } \\
\text { days } \\
\text { Temperature }^{1}\end{array}$} & \multicolumn{15}{|c|}{ Mean height $(\mathrm{cm})$} \\
\hline & \multicolumn{3}{|c|}{90} & \multicolumn{3}{|c|}{180} & \multicolumn{3}{|c|}{270} & \multicolumn{3}{|c|}{360} & \multicolumn{3}{|c|}{450} \\
\hline & 17 & 22 & 26 & 17 & 22 & 26 & 17 & 22 & 26 & 17 & 22 & 26 & 17 & 22 & 26 \\
\hline F3P4 & 0.2 & $--^{2}$ & 3.2 & 1.0 & -- & 10.3 & 3.5 & -- & 12.0 & 10.3 & -- & -- & 11.5 & -- & -- \\
\hline Jaran & 0.4 & 0.2 & 2.5 & 2.3 & 3.5 & 11.5 & 6.2 & 12.0 & 12.0 & 12.0 & 12.0 & 12.0 & 12.0 & 12.0 & -- \\
\hline Khae & 1.5 & 1.1 & 2.8 & 3.4 & 4.0 & 12.0 & 6.3 & 8.5 & -- & 12.0 & 12.0 & -- & 12.0 & 12.0 & -- \\
\hline Khai & 0.4 & 0.2 & 2.5 & 3.3 & 2.8 & 11.4 & 8.1 & 6.2 & 12.0 & 12.0 & 12.0 & 12.0 & 12.0 & 12.0 & -- \\
\hline Lidi & 0.5 & 1.0 & 2.8 & 2.1 & 2.8 & 11.0 & 5.1 & 9.7 & -- & 12.0 & 12.0 & --- & 12.0 & 12.0 & --- \\
\hline$M-53$ & 0.3 & 0.3 & 4.5 & 6.0 & 5.0 & 12.0 & 12.0 & 12.0 & 12.0 & 12.0 & 12.0 & 12.0 & 12.0 & 12.0 & -- \\
\hline M-61 & 0.2 & 1.7 & 6.1 & 2.3 & 3.6 & 12.0 & 7.6 & 12.0 & 12.0 & 12.0 & 12.0 & 12.0 & 12.0 & 12.0 & 12.0 \\
\hline Malaccensis & 0.9 & 1.5 & 2.0 & 8.0 & 3.0 & 12.0 & 12.0 & 8.0 & -- & 12.0 & 12.0 & --- & 12.0 & 12.0 & -- \\
\hline Malbut & 0.7 & 1.1 & 1.9 & 5.1 & 5.3 & 12.0 & 10.4 & 12.0 & 12.0 & 12.0 & 12.0 & 12.0 & 12.0 & 12.0 & -- \\
\hline Mambe Thu & 0.3 & 0.9 & 2.5 & 4.3 & 3.9 & 12.0 & 10.7 & 11.5 & 12.0 & 12.0 & 12.0 & 12.0 & 12.0 & 12.0 & -- \\
\hline Monyet & 1.2 & 1.3 & 2.3 & 2.1 & 3.7 & 12.0 & 5.3 & 9.0 & 12.0 & 11.2 & 11.1 & 12.0 & 11.6 & 11.8 & -- \\
\hline NBC-20 & 0.3 & 1.0 & 4.0 & 4.5 & 4.4 & 12.0 & 12.0 & 12.0 & 12.0 & 12.0 & 12.0 & -- & 12.0 & 12.0 & -- \\
\hline Niyarma Yik & 0.6 & 0.9 & 2.5 & 4.3 & 4.5 & 12.0 & 9.3 & 12.0 & 12.0 & 12.0 & 12.0 & 12.0 & 12.0 & 12.0 & 12.0 \\
\hline Ouro & 0.3 & 0.8 & 4.6 & 1.5 & 2.6 & 10.5 & 4.0 & 8.3 & 12.0 & 12.0 & 12.0 & 12.0 & 12.0 & 12.0 & -- \\
\hline PA Rayong & 0.6 & 2.2 & 3.0 & 4.5 & 3.5 & 11.1 & 9.5 & 12.0 & 12.0 & 12.0 & 12.0 & 12.0 & 12.0 & 12.0 & -- \\
\hline PA Songkla & 0.5 & 1.2 & 3.4 & 5.1 & 4.0 & 12.0 & 12.0 & 12.0 & 12.0 & 12.0 & 12.0 & 12.0 & 12.0 & 12.0 & 12.0 \\
\hline Phatthalung & 0.6 & 1.8 & 3.5 & 4.2 & 4.3 & 12.0 & 10.2 & 10.2 & 12.0 & 12.0 & 12.0 & 12.0 & 12.0 & 12.0 & 12.0 \\
\hline Raja Uter & 0.2 & 0.2 & -- & 2.3 & 3.0 & -- & --- & 12.0 & -- & -- & 12.0 & -- & -- & 12.0 & --- \\
\hline S/N.2 & 0.3 & 0.6 & 3.0 & -- & 4.0 & 12.0 & -- & 9.3 & 12.0 & -- & 12.0 & 12.0 & -- & 12.0 & -- \\
\hline Sowmuk & 1.1 & 1.9 & 3.5 & 4.0 & 4.1 & 12.0 & 12.0 & 12.0 & 12.0 & 12.0 & 12.0 & 12.0 & 12.0 & 12.0 & -- \\
\hline $\begin{array}{l}\text { Thong } \\
\text { Dokmak }\end{array}$ & 0.3 & 0.4 & 3.5 & --- & 5.3 & 12.0 & -- & 10.2 & -- & -- & 12.0 & --- & -- & 12.0 & -- \\
\hline Tjau Lagada & 0.4 & 0.2 & 2.6 & 2.0 & 2.1 & -- & 6.1 & 9.3 & 9.3 & 12.0 & 12.0 & -- & 12.0 & 12.0 & -- \\
\hline Tongat 1 & 0.2 & 0.2 & 1.5 & 2.4 & 3.6 & 12.0 & 6.6 & 12.0 & -- & 12.0 & 12.0 & --- & 12.0 & 12.0 & --- \\
\hline Tuugia & 0.1 & 0.2 & 2.8 & -- & 4.1 & 12.0 & -- & 8.3 & 12.0 & -- & 12.0 & 12.0 & -- & 12.0 & 12.0 \\
\hline Mean $^{3}$ & $0.5 \pm 0.4$ & $0.9 \pm 0.6$ & $3.1 \pm 1.0$ & $3.6 \pm 1.7$ & $3.8 \pm 0.8$ & $11.7 \pm 0.5$ & $8.4 \pm 2.9$ & $10.4 \pm 1.8$ & $11.9 \pm 0.6$ & $11.9 \pm 0.4$ & $11.9 \pm 0.2$ & $12.0 \pm 0.0$ & $12.0 \pm 0.1$ & $12.0 \pm 0.0$ & $12.0 \pm 0.0$ \\
\hline
\end{tabular}

${ }^{1}$ Mean temperature during the period of conservation. ${ }^{2}$ No survival. ${ }^{3}$ Survived plantlets only.

temperature of $22^{\circ} \mathrm{C}$, suggest replicates every 220 days. In this work, it was verified that, for plantlets kept at mean temperature of $17^{\circ} \mathrm{C}$, replicates every 450 days are recommended. This result is similar to that obtained by $\mathrm{De}$ Langhe (1984), Banerjee \& De Langhe (1985) and Van Den Houwe et al. (1995), who recommended replicates between 330 and 540 days at temperatures ranging from 13 to $17^{\circ} \mathrm{C}$.

The use of low temperatures without adjustments in the chemical components of the culture medium or modification in other physical culture conditions was sufficient to reduce the in vitro growth of the plantlets. Other changes could also be evaluated like light intensity (Banerjee \& De Langhe, 1985) and hormonal balance (Zamora et al., 1989). In the present work, the conservation of plantlets was done under light intensity of 2000 lux. However, several authors have reported that the reduction of light intensity increases viability of crops at low temperatures, since the process of tissue deterioration is reduced (Centro Internacional de Agricultura Tropical, 1984).

The banana diploid plantlets were easily acclimated. No somaclonal variants were observed under greenhouse conditions. One possible reason is that genotypes used were diploids with low number of subcultures. However, the possible presence of these variants must be suitably monitored in the field, since banana plants multiplied in vitro have showed somaclonal variation ranging from 0 to $69 \%$ (Vuylsteke et al., 1991).

\section{CONCLUSION}

- The evaluated diploid accessions (AA) show potential to be conserved in vitro for a long time.

- The in vitro behavior of studied diploids $(\mathrm{AA})$ is similar during conservation.

- The use of low temperatures, without adjustments in chemical components of the culture medium and/or in other physical culture conditions, is sufficient to reduce the in vitro development of banana diploid plantlets (AA).

\section{REFERENCES}

ARIAS, O. Commercial micropropagation of banana. In: INIBAP. Biotechnology applications for banana and plantain improvement. San José: Costa Rica, 1993. p.139-142.

BANERJEE, N.; DE LANGHE, E. A tissue culture technique for rapid clonal propagation and storage under minimal growth conditions of Musa (banana and plantain). Plant Cell Reports, v.4, p.351-354, 1985. 
CENTRO INTERNACIONAL DE AGRICULTURA TROPICAL EI cultivo de meristemas para la conservación de germoplasma de yuca in vitro. Cali: CIAT, 1984. 44p.

DE LANGHE, E. The role of in vitro techniques in germplasm conservation. In: HOLDEN, J.H.; WILLIAMS, J.T. Crop genetic resources; conservation and evaluation. London: G. Allen \& Unwin, 1984. p.131-137.

ESCALANT, J.V. Advances en biotecnologia de Musa a nível regional; oportunidades de cooperación y capacitación. In: REUNION DE COMITE ASESOR REGIONAL INIBA LACNET, 3., San Pedro Sula, 1993. Costa Rica: CATIE, 1993. 8p.

JARRET, R.L. In vitro propagation and genetic conservation of bananas and plantains. In: MEETING ADVISORY COMMITTEE ON IN VITRO STORAGE, 3., Rome, 1986. Report. Rome: International Board for Plant Genetic Resources, 1986. p.15-33.

JARRET, R.L.; FERNANDEZ, R.; SALAZAR, S. In vitro conservation at CATIE. Plant Genetic Research Newsletter, v.68, p.6-10, 1986.

LEIFERT, C.; MORRIS, C.E.; WAITES, W.M. Ecology of microbial saprophytes and pathogens in tissue culture and field grown plants: reasons for contamination problems in vitro. Critical Reviews in Plant Sciences, v.13, p.139-183, 1994.

MURASHIGE, T.; SKOOG, F. A revised medium for rapid growth and bioassays with tobacco tissue cultures. Physiologia Plantarum, v.15, p.473-497, 1962.

PANIS, B. Cryopreservation of Musa germplasm. Infomusa, V.4, p.17-20, 1995.

SANDOVAL, J.A.F.; BRENES, G.G.; SANCHEZ, L.P. Micropropagación de platano y banano (Musa AAB, AAA) en el CATIE. Turrialba: CATIE, 1991. 29p. (Informe Técnico, 186).

VAN DEN HOUWE, I.; SMET, K.; TEZENAS-DU-MONTCEL, H.; SWENNEN, R.; DE-SMET, K. Variability in storage potential of banana shoot cultures under medium term storage conditions. Plant Cell, Tissue and Organ Culture, v.42, p.269-274, 1995.
VUYLSTEKE, D.R. Shoot-tip culture for the propagation, conservation and exchange of Musa germplasm. Rome: IBPGR, 1989. 56p.

VUYLSTEKE, D.; DE LANGHE, E. Feasibility of in vitro propagation of bananas and plantains. Tropical Agriculture, v.62, p.323-328, 1985.

VUYLSTEKE, D.; SWENNEN, R.; DE LANGHE, E. Somaclonal variation in plantains (Musa spp., AAB group) derived from shoot-tip cultures. Fruits, v.46, p.429-439, 1991.

WILLIAMS, J.T. Banana and plantain germplasm conservation and movement and needs for research. In: PERSLEY, G.J.; DE LANGHE, E.A. Banana and plantain breeding strategies. Cairns: INIBAP, 1987. p.177-181.

WITHERS, L.A. Prospects and problems of in vitro genebanks. In: INIBAP/IBPGR. Musa; conservation \& documentation. Leuven: INIBAP, 1990. p.21-24.

WONG, W.C. In vitro propagation of banana (Musa spp.): initiation, proliferation and development of shoot-tip cultures on defined media. Plant cell, tissue and organ culture, v.6, p.159-166, 1986.

ZAMORA, A.B.; BARBA, R.C.; DAMASCO, O.P. Status and prospects of tissue culture research on bananas. In: UMALI, B.E.; LANTICAN, C.M. (Ed.) Banana and plantain research and development. s.l.: s.ed., 1986. p.78-88. (PCARRD Book Series, 41).

ZAMORA, A.B.; DAMASCO, O.P.; LANDICHO, S. Development of a minimal growth medium for in vitro storage of banana and plantain (Musa spp.) germplasm. Philippine Agriculturist, v.72, p.466-472, 1989.

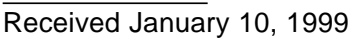

